\section{Use of Random Amplified Polymorphic DNA Markers for Cultivar Identification in Mint}

\author{
A.L. Fenwick and S.M. Ward ${ }^{1}$ \\ Department of Soil and Crop Sciences, Colorado State University, Fort \\ Collins, CO 80523-1170
}

Additional index words. Mentha $\mathrm{x}$ gracilis, Mentha $\mathrm{x}$ piperita, Mentha spicata, peppermint, spearmint, RAPDs

Abstract. Seventeen mint accessions representing the three species grown for commercial oil production in the United States were characterized using randomly amplified polymorphic DNA (RAPD) analysis. The RAPD profiles readily identified the different Mentha species; calculation of genetic distance, based on the number of shared bands, indicated that $M$. spicata $\mathrm{L}$. is more closely related to $M$. $\times$ gracilis than to $M$. $\times$ piperita. The RAPD profiles also distinguished among eight peppermint accessions of different geographical origin. However, only limited polymorphism was observed among the most widely grown peppermint and Scotch spearmint cultivars. These results indicate a potential lack of genetic diversity in mint cultivars grown for oil in the United States.

Production of mint oil in the United States is dependent on two species (nomenclature and taxonomy as perTucker andFairbrothers, 1990): Mentha $\mathrm{x}$ piperita (peppermint) and Mentha $\mathrm{x}$ gracilis (Scotch spearmint), with limited commercial production of a third, Mentha spicata $\mathrm{L}$. (native spearmint) (Johnson and Cummings, 2000). As commercial mint cultivars do not form seed, growers plant rooted cuttings or stolons to establish production fields (Mitchell and Yang, 1998). A program of registered mint propagators has been established to ensure that vegetatively propagated materials are true-totype; this has led to the need for a rapid and economical method of genotype determination that can be applied to vegetative tissue prior to increase or release to growers. Most U.S. commercial mint cultivars, especially peppermints, are difficult to distinguish using morphological characteristics. Gas chromatographic profiles of mint oils can distinguish among genotypes, but this technique is slow and expensive when screening large numbers of plants under commercial conditions, and mint oil composition can vary with environment (Tuckeretal., 1991).

An alternative technique is the use of DNA markers to generate a profile or "fingerprint" unique to a particular cultivar (Caetano-Anolles and Greshoff, 1994; Tingey and Tufo, 1993). In randomly amplified polymorphic DNA(RAPD) analysis, short DNA primers with an arbitrary sequence are used to generate genome-specific patterns of amplified DNA fragments via the

Received for publication 30 May 2000. Accepted for publication 2Oct. 2000. We thank Maria Castillo and Jennifer Owens for technical assistance. This research was funded by a grant from the Mint Industry Research Council. The cost of publishing this paper was defrayed in part by the payment of page charges. Under postal regulations, this paper therefore must be hereby marked advertisement solely to indicate this fact.

${ }^{1}$ To whom requests for reprints should be addressed. E-mail address: sward@lamar.colostate.edu polymerase chain reaction (Williams et al., 1990). This method has been used for cultivar identification and genetic analysis in a number of fruit and field crops (Gutman et al., 1999). Fingerprinting using RAPD is technically straightforward and inexpensive, and was selected for this study as the technique most readily adaptable to routine commercial use. This is the first report on the use of RAPD for cultivar identification in mint.

The goals of this study were to: 1 ) investigate the feasibility of using RAPD analysis to confirm the genotypes of commercial peppermint and spearmint cultivars; and 2) determine if the RAPD procedure could be applied routinely to plant material sent from propagators to growers, strengthening the germplasm certification process.

\section{Materials and Methods}

Seventeen mint accessions, representing three different species, were used for this
Table 1. Mentha accessions characterized by RAPD analysis. ${ }^{y}$ Summit Plant Laboratories, Fort Collins, Colo. study (Table 1). Eight $M$. x piperita accessions from different geographical origins were obtained from the U.S. Dept. of Agriculture, Agricultural Research Service (USDA-ARS) mint germplasm collection in Corvallis, Ore. Four peppermint cultivars, four Scotch spearmint cultivars, and one native spearmint clone were supplied as certified germplasm by Summit Plant Laboratories (SPL) of Fort Collins, Colo.

Young unexpanded leaves ( $5 \mathrm{~g}$ ) were collected and frozen immediately in liquid nitrogen. The DNA extraction protocol followed that of Tai and Tanksley (1990), modified by the addition of $100 \mathrm{mg}$ polyvinylpolypyrrolidine to the extraction buffer. Decamer random primers were synthesized by the Univ. of British Columbia. Amplification reactions were performed in a volume of $25 \mu \mathrm{L}$ containing $5 \mathrm{ng}$ genomic DNA, 0.2 mm each of dATP, dGTP, dCTP, dTTP, $0.5 \mu \mathrm{M}$ primer, and 10× polymerase buffer (Promega, Madison, Wis.) containing $1.5 \mathrm{~mm}$ magnesium chloride. Reaction mixtures were overlaid with $20 \mu \mathrm{L}$ mineral oil, placed in a thermocycler (Perkin Elmer, Norwalk, Conn.) and heated to $99{ }^{\circ} \mathrm{C}$ for 5 minutes to ensure complete denaturation of genomic template DNA. The block was then cooled to $85^{\circ} \mathrm{C}$ and 1 unit of Taq polymerase (Promega) was added to each tube. The samples were then subjected to 45 cycles of $1 \mathrm{~min}$ at $92^{\circ} \mathrm{C}, 2 \mathrm{~min}$ at $35^{\circ} \mathrm{C}$, and $2 \mathrm{~min}$ at $72^{\circ} \mathrm{C}$, followed by a final extension cycle of 8 min at $72^{\circ} \mathrm{C}$. Two replicates of each genomic DNA/primer combination were amplified on each run, together with a control containing all components of the reaction mixture except the template DNA. Amplified DNA fragments were separated on a $1.2 \%$ agarose gel, stained with ethidium bromide, and photographed under UV light.

A core set of 24 primers was selected as consistently producing scoreable amplified fragments following an initial screening of 50 primers with DNA from all three Mentha species. The DNA from all accessions was initially analyzed using this core set of primers. The four commercial peppermint cultivars were then analyzed using an additional 204 primers, and the four commercial Scotch

\begin{tabular}{|c|c|c|c|}
\hline Species & Accession or cultivar & Country of origin & Germplasm source \\
\hline \multirow[t]{12}{*}{ Mentha $\times$ piperita } & PI 557939 & USA & $\mathrm{USDA}-\mathrm{ARS}^{\mathrm{z}}$ \\
\hline & PI 557949 & Netherlands & USDA-ARS ${ }^{z}$ \\
\hline & PI 557951 & UK & USDA-ARS ${ }^{z}$ \\
\hline & PI 557952 ("Lavender mint”) & Brazil & USDA-ARS ${ }^{z}$ \\
\hline & PI 557953 & Brazil & USDA-ARS ${ }^{z}$ \\
\hline & PI 557968 ("Chocolate mint") & USA & USDA-ARS ${ }^{z}$ \\
\hline & PI 557978 & France & USDA-ARS ${ }^{z}$ \\
\hline & PI 557982 & Russia & USDA-ARS ${ }^{z}$ \\
\hline & 'Black Mitcham' & USA & $\mathrm{SPL}^{\mathrm{y}}$ \\
\hline & 'Todd's Mitcham' & USA & $\mathrm{SPL}^{\mathrm{y}}$ \\
\hline & 'Robert's Mitcham' & USA & $\operatorname{SPL}^{\mathrm{y}}$ \\
\hline & 'Redefined Murray Mitcham' & USA & $\mathrm{SPL}^{\mathrm{y}}$ \\
\hline \multirow[t]{4}{*}{ Mentha $\mathrm{x}$ gracilis } & 'Scotch Standard' & USA & $\operatorname{SPL}^{\mathrm{y}}$ \\
\hline & 'Scotch 770' & USA & $\mathrm{SPL}^{\mathrm{y}}$ \\
\hline & 'Scotch 213' & USA & $\operatorname{SPL}^{y}$ \\
\hline & 'Scotch 227' & USA & $\mathrm{SPL}^{\mathrm{y}}$ \\
\hline Mentha spicata $\mathrm{L}$. & Native spearmint & USA & $\operatorname{SPL}^{y}$ \\
\hline
\end{tabular}

${ }^{\mathrm{z}}$ U.S. Dept. of Agriculture, Agricultural Research Service (USDA-ARS), Corvallis, Ore. 


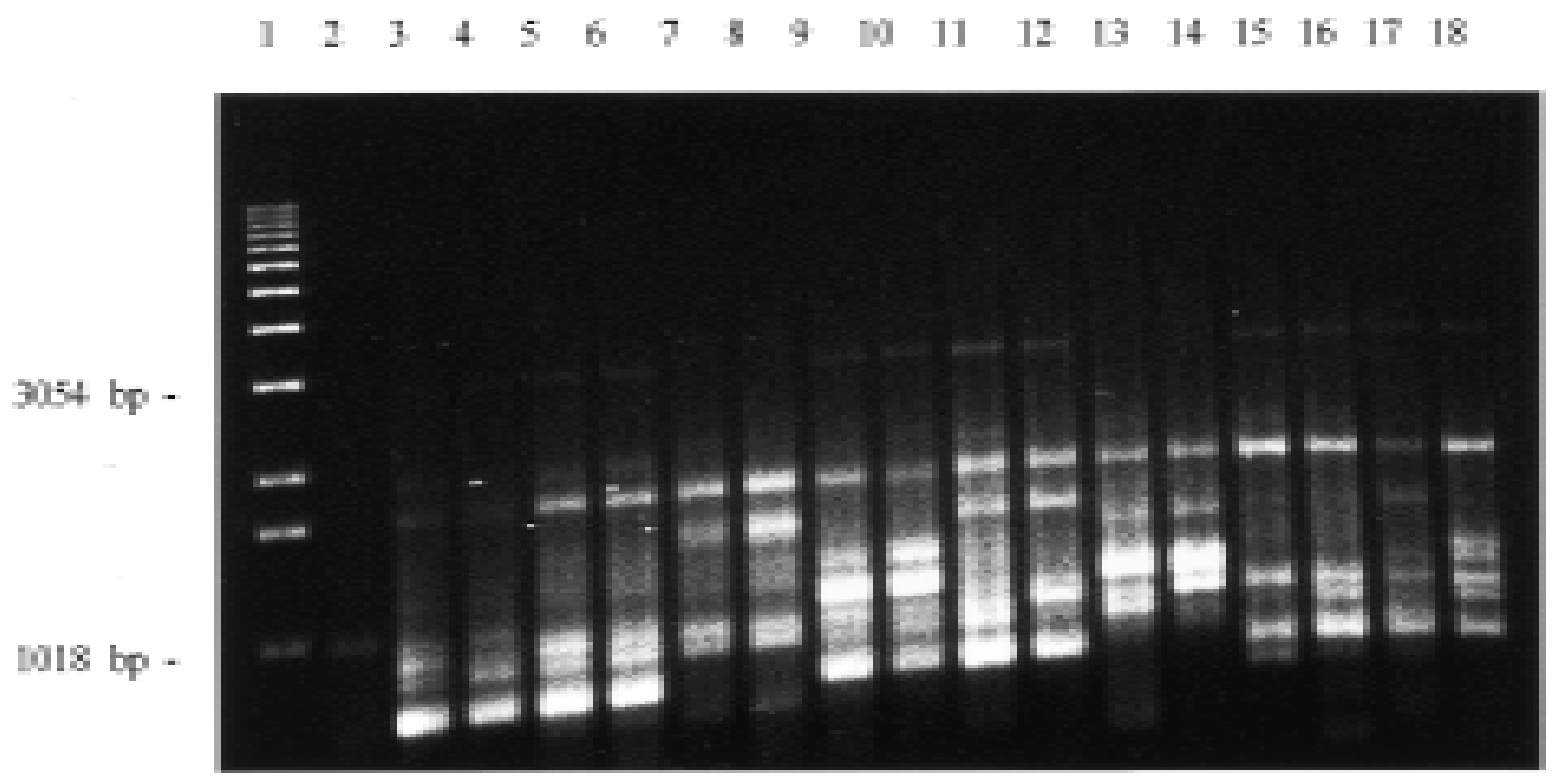

Fig. 1. RAPD profiles for eight USDA peppermint accessions amplified with UBC primer 529. Lane $1=1 \mathrm{~Kb}$ ladder (Gibco BRL, Rockville, Md.), lane $2=$ control, lanes 3-4 = PI 557939, lanes 5-6 = PI 557949, lanes 7-8 = PI 557953, lanes 9-10 = PI 557978, lanes 11-12= PI 557951, lanes 13-14 = PI 557952, lanes $15-16=$ PI 557968, and lanes 17-18 = PI 557982.

spearmint cultivars by using an additional 160 primers. A binary data matrix was constructed by scoring the presence $(+)$ or absence $(-)$ of amplified bands for each primer-genotype combination. Only bands that were consistent across replicates and repeatable on two independent amplification runs were included in the analysis. The index proposed by Nei and Li (1979) was used to calculate the degree of similarity, $\mathrm{S}_{\mathrm{ij}}$, between two cultivars $\mathrm{i}$ and $\mathrm{j}$ :

$$
\mathrm{S}_{\mathrm{ij}}=2 \mathrm{~N}_{\mathrm{ij}} /\left(\mathrm{N}_{\mathrm{i}}+\mathrm{N}_{\mathrm{j}}\right)
$$

where $\mathrm{N}_{\mathrm{ij}}=$ number of bands common to both cultivars $i$ and $j, N_{i}=$ number of bands unique to cultivar $\mathrm{i}$, and $\mathrm{N}_{\mathrm{j}}=$ number of bands unique to cultivar $\mathrm{j}$. A dendrogram was constructed using the unweighted pair-group method average (UPGMA) procedure. All computations were performed using NTSYS-pc version 2.02 (Rohlf, 1998).

\section{Results and Discussion}

The core set of 24 primers on all genotypes generated a total of 133 reproducible bands, of which 104 (78\%) were polymorphic between two or more accessions. The mean number of bands per primer was 5.5 , with 23 of the 24 core primers $(96 \%)$ generating at least one polymorphism. The core set of primers readily distinguished between the three Mentha species, and produced distinctive fingerprints differentiating the eight USDA peppermint accessions (Fig. 1). These primers did not, however, distinguish between the four commercial U.S. peppermints or between the four Scotch spearmints. The DNA from these eight cultivars was therefore screened with additional primers in an attempt to generate RAPD profiles unique to each genotype.

Screening the four commercial peppermint cultivars with another 204 primers generated an additional 802 bands, a mean of 3.5 bands per primer. Of these amplified products, four $(0.5 \%)$ were polymorphic and distinguished one cultivar, 'Todd's Mitcham' (Fig. 2). The remaining three peppermint cultivars, 'Black Mitcham', 'Robert's Mitcham' and 'Redefined Murray Mitcham' possessed identical RAPD profiles. The additional 160 primers used to screen the four commercial Scotch spearmints generated 687 bands, a mean of 3.7 bands per primer; of these three $(0.4 \%)$ were polymorphic and distinguished 'Scotch Standard' and 'Scotch 227'. No other polymorphisms were observed. Degrees of similarity between all accessions characterized are summarized in Fig. 3.

The distinctive RAPD profiles for the three mint species, and for the eight USDA pepper- mint accessions, demonstrate that RAPD can be used in mint to distinguish between species and between genotypes within a species. The RAPD technique can also be used to estimate degrees of relatedness within the genus Mentha; calculation of genetic distance based on the number of shared bands indicates that native spearmint (M. spicata L.) is much more closely related to Scotch spearmint (M.X gracilis) than to peppermint (M. x piperita) (Fig. 3). This supports cytological studies by Tucker and Fairbrothers (1990) indicating that Scotch spearmint was derived by hybridization between $M$. arvensis L. and M. spicata $\mathrm{L}$.

Given the relative ease with which the peppermints from the USDA collection could

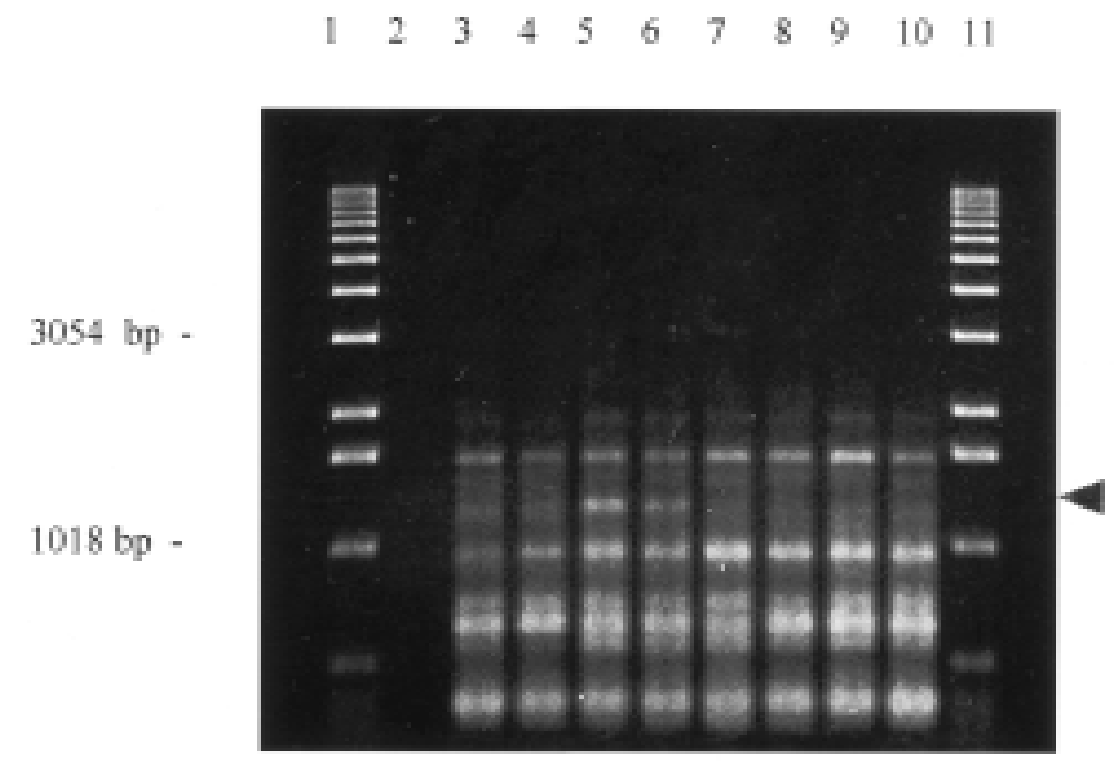

Fig. 2. RAPD profiles for four commercial US peppermint cultivars amplified with UBC primer 599. Lane $1=1 \mathrm{~Kb}$ ladder (Gibco BRL), lane $2=$ control, lanes 3-4 = 'Black Mitcham', lanes 5-6 = 'Todd's Mitcham', lanes 7-8 = 'Robert's Mitcham', lanes 9-10= 'Redefined Murray Mitcham', and lane $11=$ $1 \mathrm{~Kb}$ ladder (Gibco BRL). 


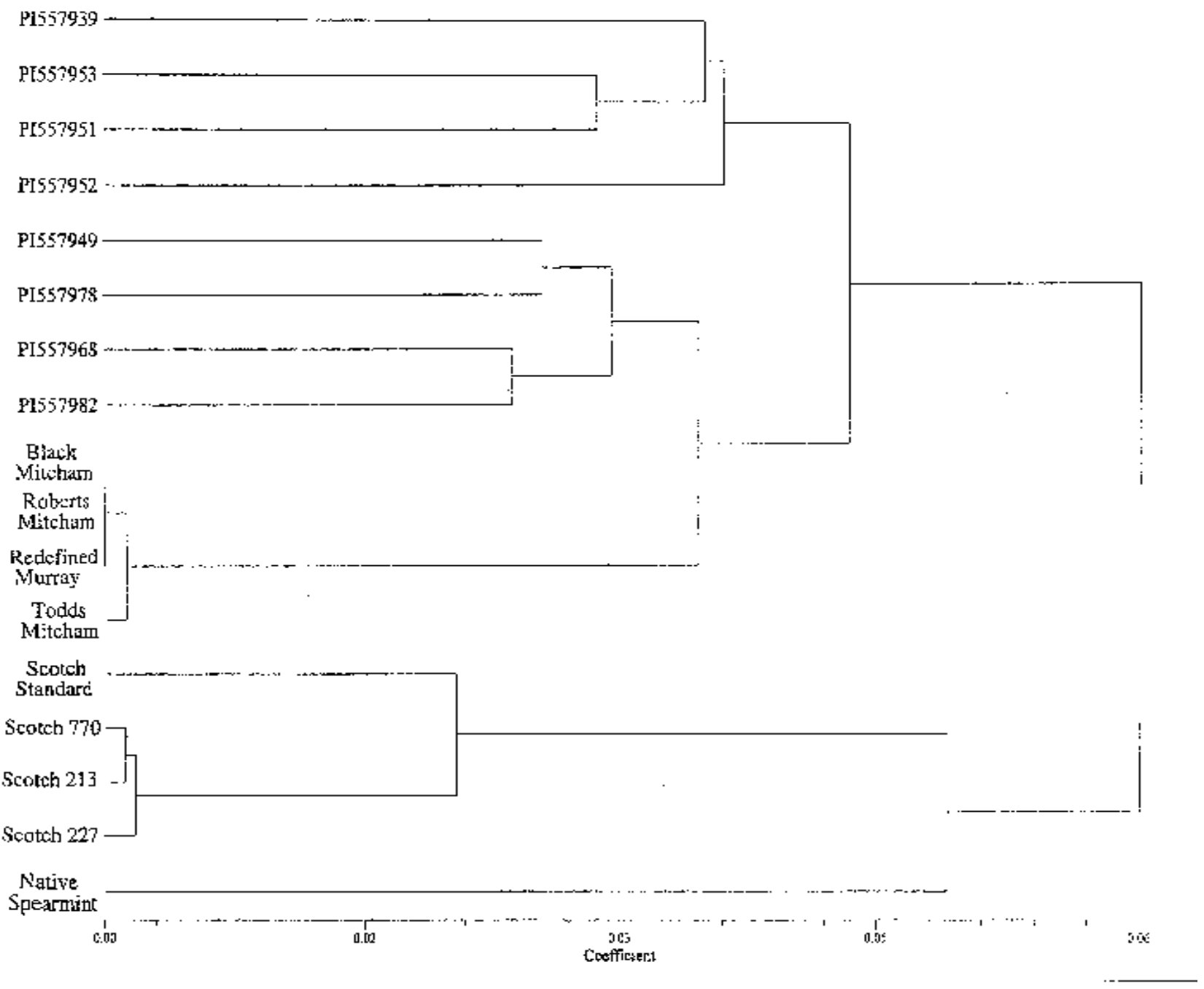

Fig. 3. Dendrogram of 17 mint accessions, constructed using UPGMA based on Nei and Lei's (1979) similarity index.

be distinguished using RAPD with just 24 primers, the lack of differentiation among commercial cultivars of peppermint using 228 primers and also among Scotch spearmint cultivars using 184 primers suggests a very high degree of genetic uniformity. Although extensive genetic variation exists in Mentha, new cultivars are commonly selected as either spontaneous or induced variants or "sports" of existing cultivars and then clonally propagated. The four commercial peppermint cultivars are very closely related, with 'Robert's Mitcham', 'Todd's Mitcham', and 'Redefined Murray Mitcham' all derived from 'Black Mitcham' by mutation breeding (Murray, 1971; Murray and Todd, 1975). Although 'Todd's Mitcham' was registered and released as a new variety (Murray and Todd, 1972) the limited RAPD polymorphism distinguishing this genotype indicates that the induced mutation used to develop this peppermint affected only small areas of the genome. Among the Scotch spearmints, 'Scotch 770', 'Scotch 213', and 'Scotch 227' were all derived by mutation breeding from 'Scotch Standard' (C. Rivera Smith, Summit Plant Laboratories, Fort Collins, Colo., personal communication). For both species, this has resulted in limited ge- netic differences between cultivars. If the distribution of priming sites within the genome does not include these key divergent areas, then RAPD profiles will be identical. This limits the utility of RAPD for confirming the identity of these commercial cultivars in the United States.

These results also indicate very little genetic diversity in peppermint and Scotch spearmint cultivars grown in the United States. One result of this is the lack of disease resistance genes in the effectively identical varieties which make up the bulk of U.S. mint plantings, and the consequent vulnerability of the crop to major pathogen outbreaks, as demonstrated by the widespread occurrence of verticillium wilt (caused by Verticillium dahliae Kleb.). This pathogen has severely reduced cultivation in Indiana and Michigan and now threatens mint growers in other parts of the country (Johnson and Cummings, 1999). Use of transgenic technology to transfer known resistance genes to existing mint cultivars with good yield and oil qualities is one approach that could alleviate crop losses due to verticillium infection. Broadening the genetic base of U.S. peppermint and Scotch spearmint cultivars by conventional plant breeding techniques, such as the introgression of useful genes from other Mentha species, would also be desirable. This approach has the potential to increase the tolerance of commercial cultivars to abiotic stresses, as well as to expand the basis of disease resistance beyond dependence on major genes.

\section{Literature Cited}

Caetano-Anolles, G. and P.M. Greshoff. 1994. DNA amplification fingerprinting of plant genomes. Methods Mol. Cell Biol. 5:62-70.

Gutman, F., A. Nerd, Y. Mizrahi, D. Bar-Zvi, and D. Raveh. 1999. Application of random amplified polymorphic DNA markers for identification of marula genotypes. HortScience 34:1256-1258.

Johnson D.A. and T.F. Cummings. 2000. Evaluation of mint mutant, hybrids and fertile clones for resistance to Verticillium dahliae. Plant Dis. 84:235-240.

Mitchell, A.R. and C.L. Yang. 1998. Irrigation of peppermint for optimal yield. Soil Sci. Soc. Amer. J. 62:1405-1409.

Murray, M.J. 1971. Additional observations on mutation breeding to obtain verticillium- resistant strains of peppermint, p. 171-195. In: Mutation breeding for disease resistance: Proc. Intl. Atomic Energy Authority, Vienna.

Murray, M.J. and W.A. Todd. 1972. Registration of 
Todd's Mitcham peppermint. Crop Sci. 12:128. Murray, M.J. and W.A. Todd, 1975. The role of mutation breeding in genetic control of plant diseases, p. 172-176. In: Biology and control of soil-borne plant pathogens. Amer. Phytopathol. Soc., St. Paul, Minn.

Nei, M. and W.H. Li. 1979. Mathematical model for studying genetic variation in terms of restriction endonucleases. Proc. Natl. Acad. Sci. USA 76:5269-5273.

Rohlf, F.J. 1998. NTSYS-pc. Numerical taxonomy and multivariate analysis system. Exeter Software, Setauket, N.Y.

Tai, T. and S.D. Tanksley. 1990. A rapid and inexpensive method for isolation of total DNA from dehydrated plant tissue. Plant Mol. Biol. Rpt. 8:297-303.

Tingey, S.V. and J.P. del Tufo. 1993. Genetic analysis with random amplified polymorphic DNA markers. Plant Physiol. 101:349-352.

Tucker, A.O. and D.E. Fairbrothers. 1990. The origin of Mentha $\mathrm{x}$ gracilis (Lamiaceae). I.
Chromosome numbers, fertility, and three morphological characters. Econ. Bot. 44:183-213. Tucker, A.O., H. Hendriks, R. Bos, and D.E. Fairbrothers. 1991. The origin of Mentha X gracilis (Lamiaceae). II. Essential oils. Econ. Bot. 45:100-115.

Williams, J.K.G., A. Kubelik, K.L. Livak, J.A. Rafalski, and S.V. Tingey. 1990. DNA polymorphisms amplified by arbitrary primers are useful as genetic markers. Nucleic Acids Res. 18:6531-6535. 